\title{
Advancing Accountability in Government
}

\section{Tony Harris ${ }^{1}$}

There are layers of accountability which governments should respect if they are to accord voters the full rights of democracy. At the basic level, governments, and their agencies, are required to publish accurate reports on their use of public financial resources. To assist the process of accountability, Australia's nine jurisdictions engage auditors-general who oversee the auditing of these financial reports. These auditors advise on whether these government reports are true and fair according to accounting requirements.

Because these reports are the foundation of financial accountability, we expect that no agency would wish to present information which fails the true-and-fair test. Alas, these expectations are not always fulfilled. For 2007-08, for example, the auditor-general for South Australia was unable to provide a clear opinion on the state's Consolidated Financial Report. A reading of that report on the government's website will show that the Treasurer, Kevin Foley, claimed that his report was true and fair. But the opinion from the state auditor-general attached to the report does not support those claims.

A more egregious example of failure to report financial matters accurately was the Commonwealth Government's view that the Goods and Services Tax, enacted by the Commonwealth Parliament in 1999, was not a Commonwealth tax. The Prime Minister, John Howard, and his treasurer and finance minister each claimed that the $\$ 40$ billion or so collected through the GST was a state (and territory) tax. This view was informed by politics. It enabled the Commonwealth to report lower taxation collections and lower spending for the period of the Howard government from 2000-01 when the GST was first collected. Happily, this position was not supported by any state or territory auditor-general, $^{2}$ or the Commonwealth Statistician ${ }^{3}$ or the Australian Tax Office. ${ }^{4}$ The Commonwealth auditor-general also found that the GST was a

\footnotetext{
1 Former NSW Auditor General (1992-1999).

${ }^{2}$ No state or territory financial report claimed the GST as a state tax and these reports were not qualified by state or territory auditors-general: see state and territory consolidated financial statements and audit opinions for 2000-01 (and relevant subsequent years).

3 Australian Bureau of Statistics: 5517.0 - Information Paper: Accruals-based Government Finance Statistics, 2000.

4 Australian Taxation Office: Annual Report 2000-01 — Note 19a of Audited Financial Statements (and relevant subsequent annual financial statements).
} 
federal tax; ${ }^{5}$ accordingly, basic Commonwealth financial reports were qualified for each of the relevant years of the Howard government.

Governments manipulate financial statements from time to time, but even unadulterated financial statements are poor tools for effective accountability. They merely show that monies received can be accounted for in the prescribed fashion and, at the agency level, they tell us little more. When government hospitals, for example, publish their audited financial reports, we might be satisfied that public monies have been accounted for in the way required of profit businesses but we have no notion about the effectiveness, efficiency or economy of these entities.

Unfortunately, while financial reports by private-sector bodies contain much of the information required by investors, creditors and employees, they are of little use in the public sector. Seeing whether a publicly listed company is profitable and has sufficient funds to meet emerging liabilities would satisfy most users of financial reports. But almost by definition, the concept of profitability is irrelevant for most central government bodies. Public schools, public hospitals, police services, the defence force, National Parks and other government agencies do not operate in a market where goods and services are exchanged for fees or charges sufficient to meet costs.

In most government agencies, financial resources are merely the means by which these bodies strive to achieve their goals. To meet the accountability gap between financial reporting and goal reporting, the Australian governments introduced the concept of performance audits in 1979. ${ }^{6}$ This was followed in 1983 by the decision of the Commonwealth Government to introduce program management in accord with the election promises of the Australian Labor Party. ${ }^{7}$

One of the main difficulties with performance auditing, shown for example in its past practice in the NSW government, was the identification of the goals of government programs. Because auditors seek to use external, rather than their own, standards to guide the auditing process, it is important that governments ascribe to their programs their articulated and measurable goals. Where these goals exist, performance auditing can assess whether government programs are efficient in the broadest meaning of that term. But the large number of government programs - and the much smaller number of performance audits undertaken in any Australian jurisdiction — means that performance auditing cannot be used as an annual, comprehensive accountability tool.

\footnotetext{
${ }^{5}$ Commonwealth Government of Australia: Consolidated Financial Statements for the Year Ended 30 June 2001 - Independent Audit Report, 18 December 2001 and subsequent consolidated financial statements and audit reports.

6 Hamburger, Peter 1989, 'Efficiency Auditing by the Australian Audit Office', Journal of Accounting, Auditing \& Accountability 2(3).

7 Australian Labor Party 1982, 'Labor and the Quality of Government'.
} 
The lack of comprehensiveness of performance audits suggests that the use of performance indicators for every government program might offer a better accountability tool. These indicators were introduced in the Commonwealth government concomitantly with the introduction of program management. We now see performance indicators in the annual reports of most government agencies and they are also used in documentation to support budgetary allocations.

Another example of their use is found in the New South Wales strategic plan. ${ }^{8}$ It takes performance indicators further by providing users with 60 performance indicators to assess whether the government's intentions in its state-wide plan are being realised. The annual publication by the Productivity Commission of the Report on Government Services goes further because it enables users to compare government achievements across similar programs in all Australian jurisdictions. Finally, the Intergovernmental Agreement on Federal Financial Relations ${ }^{9}$ shows how the Commonwealth is using performance indicators to measure the achievements of individual states and territories in agreed areas, as well as the federal payments to be made for such achievements.

Unfortunately, we are also seeing an abuse of performance indicators. The most recent published example of such abuse can be seen in the report by the Victorian Audit Office in April 2009, 'Access to Public Hospitals: Measuring Performance'. In this report, the Office noted that a public hospital manipulated the time spent by some patients in the emergency department before they were admitted to the hospital. We also see some agencies choosing not to adopt performance indicators and the choice of poor or inadequate performance indicators by governments. For example, the 2007-08 annual report of the New South Wales Fire Brigades offers no data on the time taken by fire brigade units to arrive at fire sites. The Commissioner of the New South Wales Corrective Services does not disclose in his comments on 'Key performance indicators' in the 2007-08 annual report the recidivism record for his agency.

Because performance indicators have assumed such a central role in the accountability process, and because they are open to manipulation in the same way as financial reports, there is merit in extending government audits to allow an annual audit of the relevance and accuracy of key performance indicators for each government reporting agency. A recent reading of all legislation for Australia's nine auditors-general shows that this mandate presently only exists in Western Australia. Its extension throughout the other eight jurisdictions would add to the health of the Australian democracy.

\footnotetext{
${ }^{8}$ New South Wales Government: A New Direction - State Plan Summary: at http://www.nsw.gov.au/stateplan/pdf/Summary_complete.pdf; accessed on 8 May 2009.

9 Published on the website of the Council of Australian Governments at: www.coag.gov.au/intergov_agreements/index.cfm).
} 